\title{
IN DEFENCE OF A GOOD COPY: A DISCUSSION ON CRAFT MAKING AND AUTHENTICITY
}

\section{Seher UYSAL*}

\begin{abstract}
Between the years 1941 and 1982 two crafts makers and brothers Tor and Åke Carlsson made wooden relief copies of John Bauer paintings. John Bauer was a very well known Swedish painter and illustrator who depicted scenes from folkloric stories. These stories were about dense forests, lakes, trolls, princes and witches. Although Bauer was a prominent figure who was very keen on keeping the copyrights of his work, the wooden copies became a sensation in the rural town Tranås.

The Bauer paintings and motifs were popular and very well known in Sweden and Åke and Tor Carlsson were aware they were making wooden replicas of his work but adding their own subtle interpretations. They designed and carved the Bauer works on wood and signed them with their famous inscription: "Fritt efter John Bauer (A free interpretation of John Bauer). The wooden copies were so popular they became collectors' items and can still be found in auctions today. They were not artworks, yet they exceeded the idea of craft making. "In defence of a good copy" investigates why the Bauer copies were so popular, researching the different aspects of copies and its merits as an art object or as memorabilia.
\end{abstract}

Keywords: Craft, Art, Copy, Replica, Interpretation

Received Date: 24.06.2020 Accepted Date: 22.02.2021 Arcticle Types: Research Article

*Merdivenköy mah. Uyanış sok. 12/8 Kadıköy Istanbul, seheruysl@gmail.com, ORCID ID:0000-0002-1408-8168 


\section{IYI KOPYANIN SAVUNMASI: ZANAATLER VE ORIJINALLIK ÜZERINE BIR TARTIȘMA}

\section{Seher UYSAL*}

Özet: 1941 ve 1982 yılları arasında iki zanaatkar kardeş Tor ve Åke Carlsson, John Bauer resimlerinin ahşap rölyef kopyalarını yapmaya başladılar. John Bauer İsveç’te oldukça bilinen ve halk hikayelerini resimleyen bir illüstratör ve ressam olarak tanınır. Resimlediği hikayelerin çoğunda karanlık ormanlar, göller, troller, prensler ve cadılar gibi olağan dışı bazı karakterlere yer verilir. Bauer bugün tanınan ve resimlerinin telif haklarını korumak için elinden geldiğince çabalayan bir ressam olarak bilinse de, çalışmalarının ahşap kopyaları Bauer'in doğduğu Jönköping bölgesi sınırları içinde kalan Tranås şehrinde büyük bir olay haline gelir.

İnsanlar Bauer resimlerini iyi tanırlar, Åke ve Tor Carlsson da kopya işler ürettiklerinin bilincindedirler ancak yine de işlerine kendi yorumlarını eklemeden duramazlar. Tasarımlarını yapıp oydukları Bauer kopyalarının arkasına meşhur imzalarını şöyle atarlar: "Fritt efter John Bauer (John Bauer'den serbest bir uyarlama).” Ahşap kopyalar öyle popüler olur ki müzayedelerde satılır ve bugün hala pek çok insan bir kopya daha bulabilmenin peşindedir. Sanat objeleri değildirler ancak zanaatkarlık fikrini aşmış, sınırlarını başka bir yere çekmiştirler. "In Defence of a Good Copy (İyi kopyanın savunması)" adlı bu metin Bauer kopyalarının neden bu denli popüler olduğunu, kopya meselesinin farklı açılardan incelenmesini ve bir sanat nesnesi ya da andaç olarak niteliklerini sorgulamayı amaçlamaktadır.

Anahtar Kelimeler: Zanaat, Sanat, Kopya, Replika, Yorum

Geliş Tarihi: 24.06.2020 Kabul Tarihi: 22.02.2021 Makale Türü: Araştırma Makalesi

*Merdivenköy mah. Uyanış sok. 12/8 Kadıköy Istanbul, seheruysI@gmail.com, 0RCID ID:0000-0002-1408-8168 


\section{INTRODUCTION}

Making is thinking. One of the preconceived ideas when it comes to craft making is that the maker perfects the skill in time through repetition. During daily labor, it is often maintained that the hand and the head are not connected, the hand works mechanically and there is no intellectual effort during this process. There is practice and there is theory, which are separate, reasoning can only start when labor finishes. Richard Sennett, in his well known book the Craftsman contradicts this manner of thinking and explains how the busy hand in time with repetition allows the crafts maker to create the work and think at the same time (Sennett, 2009: 175). However this paper is not merely about Richard Sennett's thoughts and comments on craft making, although it is widely encouraged and inspired by Sennett's book, neither is this paper solely about art or crafts. Its main focus is about a vague area between the two, when a good example of craft making goes beyond the expectations and passes the threshold between what may be deemed as being art or craft. Or more specifically when it has the potential to blur the area between two fields as well as terms like "authenticity", "authorship", "replica" and the way we use the terminology to discuss artworks, objects and/or disciplines.

This paper is a discussion about copies, replicas and fakes and stems from my interests as a contemporary artist and researcher. However it is not about "appropriation art" or "homage" or "referencing." Because the craft makers who are mentioned here were not interested in such terminologies, instead they intuitively made objects with the joy of creating things, just for the sake of making them and nothing else.

It is also crucial to point out these craft makers who produced the objects were not really concerned about the issue of copyrights. This makes their efforts not entirely legal but particularly interesting. They knew they were making copies, it brought money and supported their wood workshop financially and the products were high in demand. But to clarify what this paper is about we should first talk about three things: an old wood sculptors' workshop in rural Sweden, the artist John Bauer and the freely interpreted Bauer copies and also their copies, copies of copies.

\section{PJ CARLSSON'S BILDHUGGERI, THE WOOD SCULPTORS' WORKSHOP}

In 2018, the local librarian in Tranås, Magnus Grehn brought to my attention a book written and published by a modest local historian and artist Torbjörn Skobe with the title Inte Bara En Verkstad (Not Just a Workshop). The book summarized the history of the small wood sculptor's workshop which was in use in early to mid 1900s and which left an indelible mark on the town's history (Skobe, 2008:13). What was more compelling was that the workshop still existed intact and untouched, even though no one was actively using it anymore.

PJ Carlsson's history goes back as far as 1900s. In 1908 PJ Carlsson opened a specialist carpentry workshop which supplied handmade decorations of wood for the furniture factories in Tranås (Skobe, 2008: 14). After PJ, his sons Åke and Tor took over the family brand and expanded and enriched it with the contribution of other master crafts people. Interestingly over the years the workshop became a hub for people who are interested in all kinds of creative production since PJ himself took lessons of decoration and design from Hermann Norrman, a renowned painter who reached national recognition and lived in Tranås.

At PJ Carlsson's Bildhuggeri apart form the business of woodcarving there were also many artistic debates taking place, often with the accompaniment of music. The wood sculptors' 
studio created an intellectual circle for the town for a long time, it was always at the threshold; somewhere between professional and amateur. The place provided a shelter for creative people, a space to think, work and discuss, the studio presented another kind of creative space, somewhere between arts and crafts, art and labor for artists and enthusiasts. The workshop was not a place for individualism but rather it had a sense of unity situated in a small town where the opportunities were limited. The people at the workshop were not limited solely by one form of discipline or task but they were carpenters, artists, artisans, thinkers and musicians. The people made the place. The space today manifests itself as a kind of time capsule, a heritage site where things have mostly remained as they were before, except for the people who were once present, the 'originals' as they were often referred to.

After almost forty years since its closure the workshop is still preserved in its present condition thanks to the protection of the Tranås municipality together with the wishes of the building's previous owner Lars Gärskog. The workshop with its sepia colors appears almost frozen in time with outdated working tools and the silence that now surround them. It also remains surprisingly unknown to the local community even though it is quite easy to visit the place.
Upon reading Torbjörn Skobe's book Inte Bara en Verkstad, 1 started to research the workshop and interviewed some of the last remaining people connected to PJ Carlsson's Bildhuggeri. I collected information on some of the many artists who worked at Bildhuggarverkstad, gathered legends and hearsay about the place, examined some of the replicas and decorative objects that were produced at the workshop and more importantly have explored the place artistically as a site of local heritage.

After a year of research I compiled my research material at a website with the project name; Bildhuggarverkstad or A Story In Six Chapters (http-1) which functions both as an archive and a research based artwork. The main focus of the project was to question the issue of heritage and space and its maintenance. How do we deal with cultural heritage? Do we need to turn everything into a mausoleum? Which issues and topics make a site relevant to cultural history? The outcomes of the research were exhibited and installed at the workshop following different themes on six occasions in 2019. Although the work was completed after two years, the questions it raised did not end there. One of the six exhibitions was about the Bauer trolls and was titled "Copies or Fritt efter John Bauer (A Free interpretation of John Bauer)" (http-2). It brought together

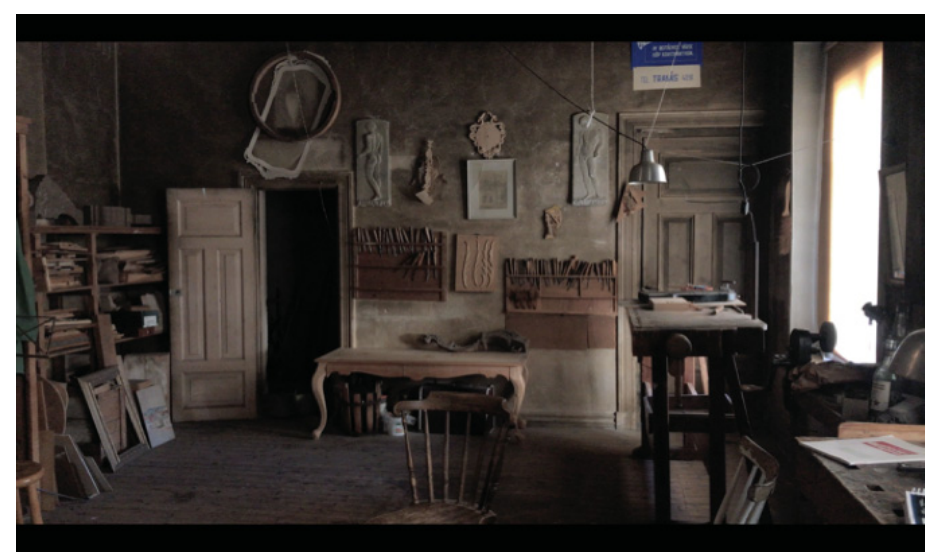

Image 1: PJ Carlsson's workshop in 2020. 
samples of a number of Bauer wooden reliefs from PJ Carlsson's Bildhuggeri and the authenticity of these wooden works were debatable. Before opening up a discussion on notions of authenticity and copies, I need to briefly introduce John Bauer and his prominence as a figure in Swedish culture.

\section{JOHN BAUER AND SWEDISH FOLK STORIES}

John Bauer is a well known Swedish artist, born in Jönköping in 1882. Today he is still very much revered and some of his works, sketches, notebooks are exhibited in the regional museum in Jönköping. Most of his works are watercolors and prints and they depict folkloric scenes, fairy tales, forests, gnomes, princesses, trolls, witches and wild animals, many of which have helped shaped the fairy tales of the Swedes and their relationship with magic in nature. He is also known to paint oils and murals in a number of churches and buildings.

Before his premature tragic and fatal drowning accident in lake Vättern in 1918, Bauer had a productive and fruitful life painting mythical scenes of the Swedish forests, landscapes and folklore. He is nationally well known and some of his works are in national collections. He studied in the Royal Academy of Arts in Stockholm where he met his painter wife Ester Ellqvist, after traveling a while in Europe they settled in their house in Gränna, Sweden. The house is still kept today but is not open to public.

Bauer painted landscapes that typically illustrate the Swedish geography, especially the region where he was born and grew up: Småland. Dense forests, rivers, lakes, dark woods, starry skies, harsh winters. He is mostly known for his illustrations of Bland tomtar och troll (Among Gnomes and Trolls) an anthology of fairy tales in which he placed otherworldly creatures like trolls and witches in his uncanny landscapes (Swedish Folk Stories, 2017, p.237). He was asked to illustrate Among Gnomes and Trolls in 1907 and his works were to accompany to a number of prominent Swedish authors' stories. He illustrated many versions of the fairy tales and was keen to keep his copyrights.

\section{A FREE INTERPRETATION OF JOHN BAUER}

In 2018 I interviewed Catherine Bolehed (C. Bolehed, personal communication, December $16,2018)$ who is the daughter of Tor Carlsson, the younger brother who took over the family business along with Åke, from their father PJ Carlsson. She has quite a large collection of local art, works she inherited from her own father as well as material collected from second hand stores around the region. Bolehed kindly lent me a collection of eight Bauer copies for the third installation of Bildhuggarverkstad and A Story in Six Chapters exhibitions. She later sold one of the copies of Leap the Elk to a friend who bought it as a gift to me knowing I would have liked to have one of the copies. I was aware that the copies were well sought after, relatively expensive and difficult to find, sometimes showing up on online auctions. The following section will try to formulate why those copied objects had become so valuable.

The Bauer copies or "free interpretations of Bauer" were very popular and were made when the business was wavering at the workshop. Mostly it was Tor Carlsson designing them and Åke Carlsson doing the carving but there are examples of Åke doing the design even though there are not that many. The first example of Åke's design which I came across is from 1941 and there are versions from 1982, indicating that they were being made for more than forty years.

The objects are wooden, usually square shaped and around 30x30 centimeters in size. Bolehed vaguely remembers her father with a tracing paper copying John Bauer's illustrations to be carved for the next day. 


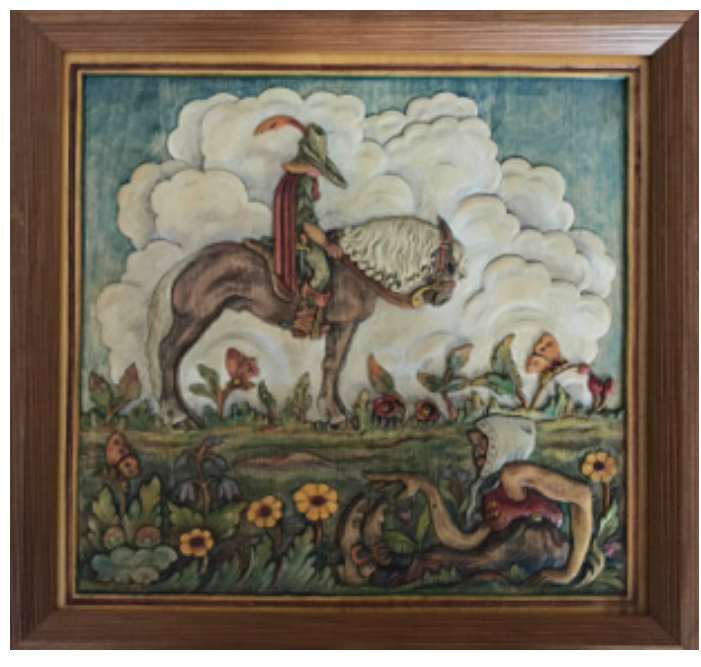

Image 2: the Troll Ride, Tor Carlsson, wooden relief, $30 \times 30 \mathrm{~cm}$, Catherine Bolehed Collection, Motala

Lars Gärskog who owned the building containing the workshop for a long while and befriended Åke and Tor says "They had no creative interest in making the copies other than financial reasons" (L. Gärskog, personal communication, June 12, 2018). A local musician Anna Hultman who had access to the workshop and rehearsed there with local musicians after it was closed states that a lot of people in Tranås have Bauer copies hanging on walls in their homes. One of her own wooden Bauer carvings has a silver plaque on, stating that it was a gift from a factory owner. She believes a lot of factory owners bought many of these Bauer copies and gave them as five or ten year anniversary gifts to their employees (A. Hultman, personal communication, April 21, 2019).

People were also known to keep them as objects for their children. One such story belongs to Peter Lundberg who lives in Gothenburg. His grandfather started a fur business in Tranås and his son took over the business but brought it to bankruptcy. Lundberg's mother and father only stayed married for a while and were separated when she was pregnant. Peter Lundberg moved to Gothenburg with his mother but received presents from his father from time to time. A fur coat, a Bauer copy. He told me that he had had a wooden Bauer carving by his bedside for more than seventy years and did not know where it came from until I placed an advertisement on social media looking for the wooden replicas. "I always had this picture and I knew it was made in 1941. I was born in 1942 and of course in 1941 I knew that my mother was living in Tranås. So I have always been intrigued by the story behind the picture and where it came from. It was very strange to have a John Bauer carving and I remember reading those books with his illustrations. Everyone in my generation read those books. So I know his illustrations but it is only now, 76 years later, that I finally know where my wooden Bauer comes from. The origins and the people who made it, is no longer a mystery to me (P. Lundberg, personal communication, May 2, 2019)."

There are many versions of the copies and in Torbjörn Skobe's book there are three dimensional sculptural examples of Bauer copies as well. The most well known versions are around eleven and are illustrations for the tales Leap the Elk and Little Princess Cottongrass (two), the Troll Ride, the Changeling, The Boy and the Trolls or the Adventure and some were titled as the Troll family or the Motherly Love (Skobe, 2008:136). There are also copies of St Francis and birds even though it does not refer to Swedish folk stories they can also be found in private collections in Tranås. The reason why they moved from folkloric tales to religious iconography remains a mystery.

Regarding why the Carlsson brothers started making wooden Bauer copies, we know two things: The first is that they started to carve these copies when the business was diminishing which meant it had economic reasons. The second motivation was that they of course, enjoyed making these woodcarvings and they were much 


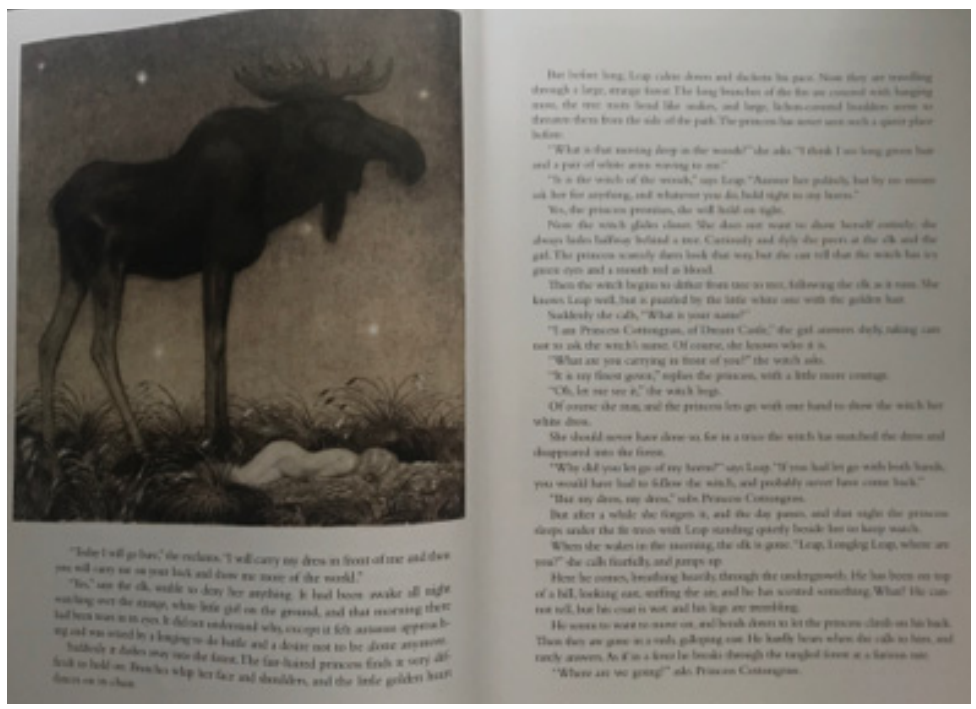

Image 3: Page from the book Swedish Folk Stories, showing John Bauer's illustration of Leap the Elk.

more than mere copies. They were inspired by Bauer however their wooden versions were never identical to Bauer's drawings. They were free interpretations. Per Tidman, who worked at the workshop (and who was Tor and Åke Carlsson's nephew) agrees that Carlssons enjoyed making these objects (P. Tidman, personal communication, August 25, 2018).

\section{LEAP THE ELK AND LITTLE PRINCESS COTTONGRASS, A KEEPSAKE}

Leap the Elk is one of those woodcarvings produced at the workshop to boost business and was part of the Bildhuggarverkstad or A Story in Six Chapters installations. It is also one of the most well known of the Swedish folk stories. To understand how Carlsson brothers operate and how other woodcarvers in Sweden used Leap the Elk as a template, I will use it as an example to distinguish the different characteristics between the original Bauer and its copies.

Leap the Elk and Little Princess Cottongrass is a tale by Helge Kjellin about a young princess "ready to see the world" with the help of an elk living in the depths of the forest and guiding the little princess through the many evils. The original Bauer illustration that accompanies the story is quite plain, the size of the animal dominates the picture and under the elk's feet we see a young princess sleeping on the grass, amongst moss and lichens. Above them we see a starry night at the background (Swedish Folk Stories, 2017, 44). This story in fact has two illustrations by Bauer which was later copied and carved on wood by Carlsson brothers.

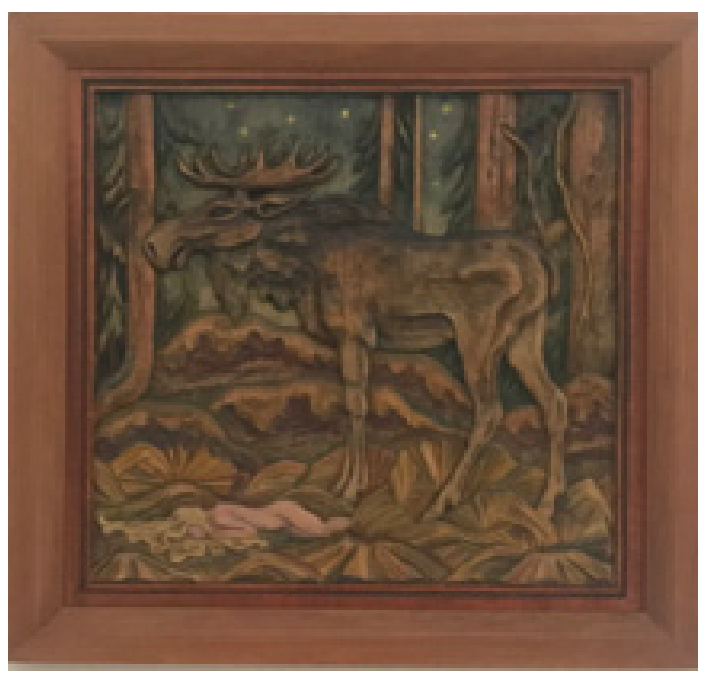

Image 4: Tor Carlsson, "Leap the Elk", wooden relief, $30 \times 30 \mathrm{~cm}$, Istanbul 


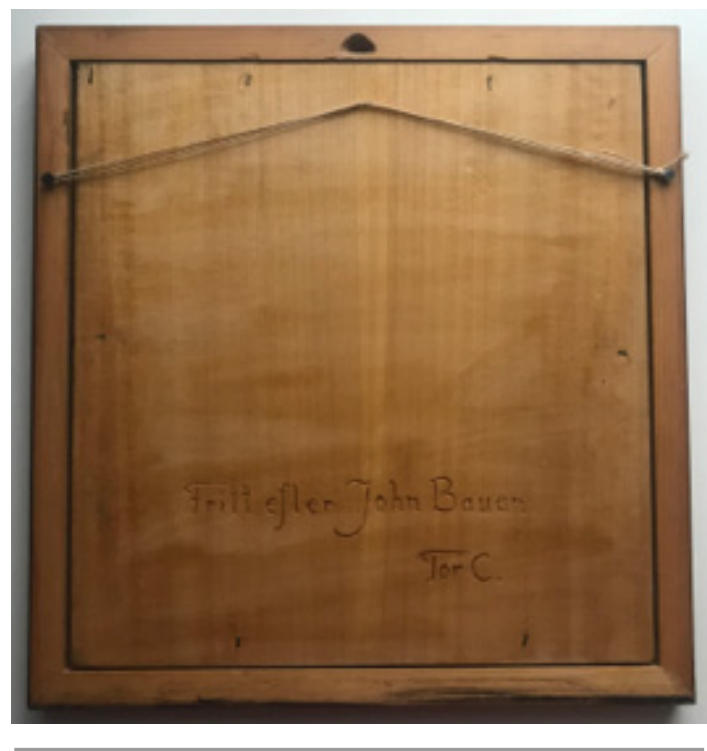

Image 5: Tor Carlsson, "Leap the Elk" (backside), wooden relief, 30×30 $\mathrm{cm}$, Istanbul.

The wooden Bauer relief which I have in my possession is slightly different than the original illustration. First of all, the direction the elk is looking at and the position of the princess differs from the Bauer version. The reason is probably the way it was copied because they had to mirror the image when making the template. The moss on the forest floor is far more dense in the Carlsson brothers' copy and there are no flowers in the background and one can see the typical Småland forest with spruce trees, the trees are so dominant they cover the sky scape. Also there are far too many stars. It's easy to state that Tor Carlsson's version is far more crowded and darker than the authentic Bauer image. There is calmness, serenity and a mystery of a young girl discovering the world in Bauer's Leap the Elk whereas there is an uncanny feeling due to the denser forest and moss in the wooden copy. On the back of the relief there is the signature of Tor Carlsson with their trademark inscription "Fritt efter John Bauer"- Tor Carlsson" ( A Free Interpretation of John Bauer - Tor Carlsson) carved into the wood.
As mentioned before my copy was a gift and gift giving is an important aspect when discussing Bauer copies and why they have become so popular in this small town. Leap the Elk in my collection was also a gift to Catherine Bolehed and she was aware I was very fond of them. The way the copies changed hands, brings forward this emotional aspect we attribute to objects.

Peter Lundberg who never knew where his Bauer copy came from was aware of only two things: One was that it was a copied version of a John Bauer illustration because he knew Bauer and he grew up with those folkloric stories. Second, it was a gift from his father, given to him when he was a baby, he did not have the chance to get to know his father properly, they were living in different sides of the country but he attached some emotional value to it. One of the reasons why these copies became more important to people than the original Bauer paintings is related to our understanding of past and attachment to nostalgia. "Now that I'm getting older I'm really enjoying the idea of being an old person, because I'm enjoying the past more and the past to me is a thing you can go back into and start understanding properly the things that happened. Past is a living thing, you can go back to your past and understand it, experience it. Sometimes I feel that the future is coming and there is not much to do about it but the past can change all the time in a deeper, more meaningful and a more inclusive way" Lundberg explains (P. Lundberg, personal communication, May 2, 2019).

Lars Gärskog also stated that he bought four copies, one for each of his children and one for himself (L. Gärskog, personal communication, June 12, 2018). Catherine Bolehed has a few specifically signed for her and Lundberg had his own copy. The impression I got during the interviews with the owners was that the carvings often reminded them about a past they like to revisit and fondly remember. 
Another important point is about access to art. Bauer paintings are in museum collections and were harder to reach and experience than the wooden copies especially at a time when color prints were not so common, high in quality as today and long before circulation of images brought on by the digital era. The Carlsson brothers created cheaper versions of John Bauer works with folkloric images in financial value but they never really created exact copies. They intuitively made changes, darkened or softened the stories, added objects and plants, adapted the shape of the clouds and stars. The original Bauer was in the museum whereas copies were in the wood sculptor's workshop, easily purchased to be hung on walls.

Another reason would be about the touch: the wooden reliefs are not just mere copies, it is easy to touch and feel the pictures and imaginary landscapes. They are tactile objects. They can be read with the help of touch, like the Braille alphabet, one can easily read the wooden relief with the help of bumps and feel the landscape, the trees, the elk. The intelligence of the hand is not a new subject; scientists have researched how homo sapiens evolve through the centuries; how the hand gripped, sensed and produced the tools, how hands are able to do a number of varied complicated movements with the cooperation of the mind. In his book The Craftsman Sennett explains the significance of touch:

"Touch poses different issues about the intelligent hand. In the history of medicine, as in philosophy, there has been a long standing debate about whether touch furnishes the brain a different kind of sensate information than the eye. It has seemed that touch delivers invasive "unbounded" data, whereas the eye supplies images that are contained in a frame. If you touch a hot stove, your whole body goes into sudden trauma, whereas a painful sight can be instantly diminished by shutting your eyes. A century ago, the biologist Charles Sherrington reformatted this discussion. He explored what he called the 'active touch,' which names the conscious intent of guiding the fingertip; touch appeared to him proactive as well as reactive." (Sennett, 2009:152)

From gripping and touching an object with your fingertips, the unity of movements with fingers, wrists and forearms to the cooperation of the eye and nerve system, the hand creates a unity with the head. Kant stated "The hand is the window to mind" (As cited in Sennett, 2009). Touching an object like the Bauer reliefs, brings one closer to actively exploring the painting, the works suddenly feels within reach, open to interpretation, the finger tips react to the object.

The importance of local cultural history also plays an important part in the value people attribute to these wooden reliefs. Sweden is often seen as being virtuous regarding archives and collecting local histories. The municipality in Tranås has published many books about the town which only has a population of less than eighteen thousand people. These books can be about the stories of famous local people, or the outdoor sculptures which can be seen around town, the history of the town or even drone photography. Since PJ Carlsson's workshop was part of their local history, people certainly would want to preserve it as part of their local heritage and buy (or own) wooden reliefs from the workshop. This might be considered as another form of nostalgia since Svetlana Boym describes this modern nostalgia as "a mourning for the impossibility of mythical return, for the loss of an enchanted world with clear borders and values; it could be a secular expression of a spiritual longing, a nostalgia for an absolute, a home that is both physical and spiritual, the edenic unity of time and space before entry into history. The nostalgic is looking for a spiritual addressee. Encountering silence, he looks for memorable signs desperately misreading them." (Boym, 2009: 33) 
Thus taking the artwork out of the museum and making it accessible to an audience in a specific locality, creating an object within reach, an object coming from a workshop people know and visit all played a part in why the Bauer copies from PJ Carlsson's workshop became so popular.

\section{ANOTHER MYSTERIOUS ENCOUNTER}

Upon finishing the project Bildhuggarverkstad or A Story in Six Chapters, I met Peter Nyberg, a translator, writer and literary developer. Nyberg was aware of the project and the website. As we were going through the documentation of the third installation Copies or Fritt efter John Bauer with him, he mentioned his grandfather made almost the same sort of wooden Bauer copies and he was quite surprised of the coincidence. Infact, Torbjörn Skobe in his book mentions Tor and Åke were aware of other people making Bauer copies but they thought their skills were of no match to themselves. (Skobe, 2008: 137) Later on Nyberg sent me two photographs of his grandfather's version of Bauer copies, one depicting Saint Francis and the other one is Little Princess Cottongrass by the lake. The color scheme was quite different and the carving looked much rougher than the ones by Carlsson brothers' copies. The sizes weren't always square but rectangular too. The encounter with Peter Nyberg's carvings, indicated that the carvings were also a trend, rather than something just to keep the business open at PJ Carlsson's, they were a phenomenon all over Sweden. Probably also connected to the growing and widespread interest of handcrafts by hobbyists in Sweden during the time. Maybe Åke and Tor got the idea of carving wooden copies of Bauer because some other craftsmen were making it around the same time. This area in history, especially the history of woodcarving and men is not much written upon, even in Swedish, according to the Regional Crafts Developer Niclas Flinck (N. Flinck, personal communication, December 12, 2020). But the interest in handcrafts is not a new concept in Sweden, in fact it has a long history and can be seen as an educational model.

Swedish interest in craft making goes back hundreds of years. Craft making helped family units become self sufficient and also it meant people with special technical skills could work in exchange for food or a little money. With the development of urban communities the "craft makers became townsmen and this led to formation of guilds" (Arvidsson, 1989:157). Internationally known craft making became an important element in Swedish educational system with the contribution of a well known educator and key figure in craft making; Otto Salomon. Salomon introduced the word Slöjd; an old Scandinavian word, stemming from the adjective slög which means 'handy' Slöjd means 'craft' or 'manual skill' (http-3). "Later on the meaning of the word has narrowed, shaped by history's course" explains Niclas Flinck and elaborates how the Slöyd model contributed to the educational system in Sweden:

"The internationally known Swedish Slöyd model in education, driven by Otto Salomon put Slöyd in the education system in Sweden, which puts values in place in organized form for almost all citizens. But the popular movements in civil society were afraid we would lose values of the preindustrial society. Especially the Friends of Handcraft and later The Swedish Handcraft Society (which both were driven and dominated by women and textile, perhaps the main reason why there is so little written about men and wood) and the National Handcraft Council which makes it a matter for the state. One important other factor is the unions and the regulation of work to get free time for hobby (N. Flinck, personal communication, December 2020)."

Flinck also states craft making is still a large part 


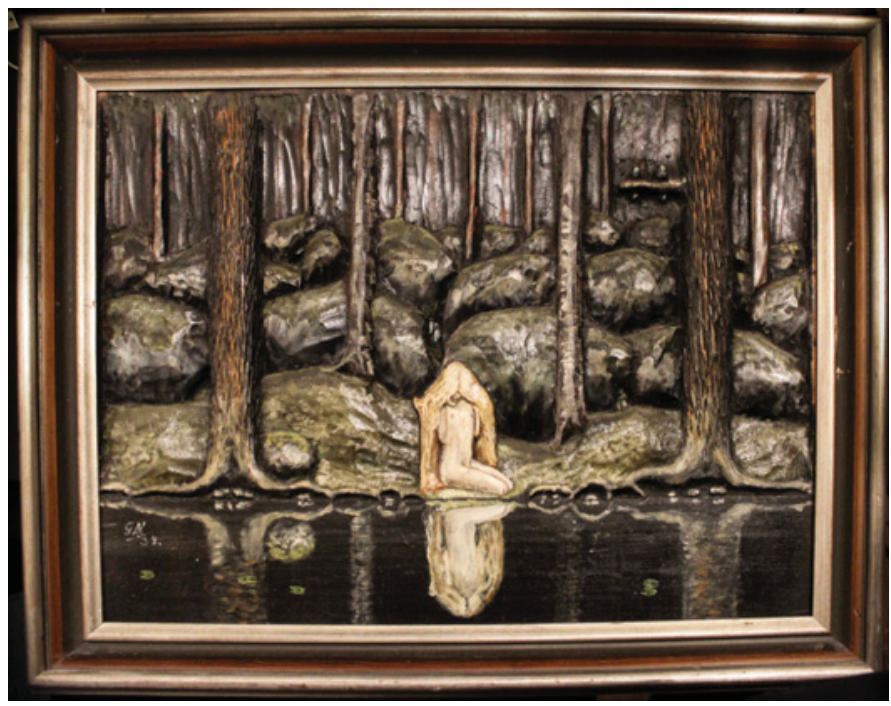

Image 6: Gösta Nyberg, "Princess Cottongrass", Jönköping, Peter Nyberg Collection.

of cultural and intangible heritage even today. Although it is difficult to predict what is the exact percentage of people interested in craft making demographically, "the statistics show that about $48 \%$ of the population is still involved in working with their hands in their free time (N. Flinck, personal communication, December 12, 2020)." Flinck explains that roughly $40 \%$ of them are male. "Why people do this is almost impossible to grasp, but Slöyd has always been something between necessity and expression, between agency and folk art and of course it takes place in a social environment (N. Flinck, personal communication, December 12, 2020)."

Since none of the people from the workshop are alive today, I had to collect the information on craft making and carving wooden Bauer copies from second hand sources. One of those sources, Peter Nyberg's father, Hasse Nyberg later told me what he remembered, explaining his father wanted to go to an art school but his family thought it was a waste of money. He had to paint in the evenings typically like an enthusiast and he loved carving and carved boxes as well as Bauer copies. He earned enough so that he could pay for most of his summer cottage with that income.
But Hasse Nyberg also knows that his father "got the idea to make John Bauer's copies from someone who had made such paintings so most probably he knew other people were making copies too. But "I don't think he knew anyone else personally," he adds. It was a hobby, "I think it was quite common to work with wood and paint in the past among the old men, while the aunts sat and and knit. Several of his acquaintances were doing so. You didn't have a TV at the time so you wanted to work on something (H. Nyberg, personal communication, May 8, 2020)." The model that Otto Salomon presented came out around 1870 when he first became the superintendent of a craft school in Nääs, one of Sweden's first schools of Crafts. His idea of craft education "though modified during the 1930s and 1940s remained the paramount method in schools because $90 \%$ of teaching was done by class teachers. The remaining $10 \%$ was done by specialized teachers who had basically trained as craftsmen. These teachers mainly served in urban schools" (Arvidsson, 1989:157). One can easily hypothesize the year Bauer copies came around craft making was still a very important part of the educational system. 
Hasse Nyberg also stated the first Bauer copy his father made was dated 1939 and in 1941 Carlssons started making their first copies. Furthermore Hasse Nyberg proves, carving Bauer copies were a common activity for amateurs and woodcarvers. What the Carlssons did was to perfect the form, carve it delicately, reinterpret the Bauer illustrations and add their inscription and signature. They were aware their productions were "free interpretations", paying their respects to the original artist John Bauer but somehow signaling they created something out of it. What they had created for almost forty years were "free interpretations of John Bauer."

\section{A DISCUSSION ON REPRODUCTION AND AUTHENTICITY}

The issue of replicating Bauer works or the notion of the copy are not new discussions. Contemporary Art history is full of examples of artworks which cite other artist's work. "Appropriation art", "homage", "pastiche" or "reference" commonly used to define such works. Even though appropriation can be traced back to the Cubists and their use of borrowed material, the term is often considered to have had its breakthrough with Marcel Duchamp's work. From Duchamp's L.H.O.O.Q referencing Da Vinci to Sherrie Levine citing Duchamp (or Walker Evans or Edward Weston) or the whole series of appropriation art by the Feminist artists such as Shigeko Kubata or Carolee Schnemann, there has been an ongoing discussion on the issues of copy rights and authenticity within contemporary art.

L.H.O.O.Q is considered to be a rectified or assisted readymade and is an important work when discussing appropriation art. It is "a cheap chromolithograph reproduction of the Mona Lisa, to which Duchamp added a beard, mustache and the inscription L:H.O.O.Q. (pronounced in French as Elle a chad au cul, 'she has a hot ass." (Ades et al. 1999: 132) This small addition was considered to be an act of iconoclasm and almost blasphemy to some at the time. Although Duchamp changed the course of art with his ready mades, references and conceptual works, he could not avoid being referenced himself. Duchamp's Fountain was later reproduced by the artist Sherrie Levine. Levine lifted Duchamp's Fountain to another level, her version of Duchamp's 'urinal' was in polished bronze cast. Levine, in her work, discusses the multiplicity of images which are almost an imposition on the viewer and "how this multiplicity weakens the position of the original image." (Şahiner, 2008:120)

There is an unending list of artists when it comes to reproductions, replicas, remakes or homages. Shigeko Kubata and Carolee Schnemann questions the esthetic values imposed upon the society by the patriarchal hegemony. Elaine Sturtevant's Repetitions and her copies of Frank Stella and George Segal, Cindy Sherman's History Portraits, Richard Prince's Cowboy Series amongst many others create a substantial inventory of artists utilizing these methods to conceptually question an idea, an opinion and/or perspectives.

There is also a history of scholarly work written on the subject matter. Walter Benjamin's prominent essay The Work of Art in the Age of Mechanical Reproduction (Benjamin, 1998:217) and Hito Steyerl's more recent article In Defence of Poor Image amongst many others provide comprehensive insights on the ideas surrounding replication, something which is especially relevant in digital discourse.

Walter Benjamin's critique stems from the term "aura" which can be explained as the uniqueness and authenticity of an art object in a particular physical space. Benjamin argues with the mechanical reproduction of the image, along with motion pictures (cinema), the value of the artwork moves to another dimension since it is 
no longer in a fixed place and it is multiple. It loses its aura but in the process of reproduction, art gains other values and functions. Thus the value of the art object changes as societies change their understanding of values. "The uniqueness of a work of art is inseparable from its being imbedded in a fabric of tradition. The tradition itself is thoroughly alive and extremely changeable (Benjamin, 1998:223). " Benjamin was discussing an image which was reproduced mechanically whereas in Hito Steyerl's world the plight of the image is digital. It is a poor image because it lacks quality, it has bad resolution, but it is accessible: "It is a ghost of an image, a preview, a thumbnail, an errant idea, an itinerant image distributed for free, squeezed through slow digital connections, compressed, reproduced, ripped, remixed, as well as copied and pasted into other channels of distribution." (http -4) But even though the image quality might be bad, it has the potential to carry other meanings, because with the help of media it is about to circulate and travel fast, creates discussions and debates, it provokes. Hence the poor image, contentwise, is richer. "By losing its visual substance it recovers some of its political punch and creates a new aura around it." (http -4) Both Steyerl and Benjamin deal with the issue of reproduction in different times either through mechanical or digital methods. Their essays are a critique on technological developments and an exploration of their effects on art and media, through the reproduction/ printing of an image or the distribution of the image through digital means. The Bauer copies on the other hand are rather a part of history itself, looking back on a time where the technologies were limited and people were still dependent on handmade tools. The way the Carlsson brothers utilized craft making as a means to reproduce the image, shows a very different aspect of reproduction of images because their aim was not just merely to copy but to embellish and reinterpret.
This paper has focused on specifically on craft making from a context unbound from mechanical and digital reproduction, where the skills of the hand and production of things goes beyond the limitations of craft making. In most discussions about art as a discipline we often imply that the artwork is unique, an original, produced by one artist or a group of artists with a specific artistic aim whereas crafts making can be a collective effort without authorship, produced in numbers by craft makers perfecting their skill through repetition. Certainly all of these are widely debated but this is one of the misconceptions when it comes to compare the distinctions between both fields. Sennett argues:

"Few Renaissance artists in fact worked in isolation. The craft workshop continued as the artist's studio filled with assistants and apprentices, but the masters of these studios did indeed put a value that was not celebrated on the originality of the work done in them; originality was a value that was not celebrated by the rituals of medieval guilds. The contrast still informs our thinking: art seems to draw attention to work that is unique or at least distinctive, whereas craft names a more anonymous, collective and continued practice. But we should be suspicious of this contrast. Originality is also a social label and originals form peculiar bonds with other people (Sennett, 2009: 66)."

One of the problems with originality according to one of the most prominent scholars of this century, Umberto Eco, is the meaning it carries, its own definition. Originality of a work can change from time to time, from person to person. Eco in his essay Original and Copy tries to define what original is through its opposite: Copy. Eco believes that everyone has an idea about what a fake or forgery is but people choose to rely on experts and their expertise in order to distinguish between a fake and an original (Eco, 1992: 273). According to Eco the terms to define a copy, 
a fake or a pseudo is difficult because "many difficulties in defining these terms are due to the difficulty in defining the notion of 'original' or of 'real object' (Eco, 1992: 273)." Since we have difficulty in defining what the original is, we cannot be exactly sure what makes a fake, fake.

Sennett also follows the word "originality" and traces it to one Greek word, "poesis," which used to mean 'something where before there was nothing.' (Sennett, 2009: 69). According to Sennett originality is a label and what it actually means changes through time:

"Originality is a marker of time; it denotes the sudden appearance of something where before there was nothing, and because something suddenly comes into existence it arouses in us emotions of wonder and awe. In the Renaissance, the appearance of something sudden was connected to the art - the genius if you will- of an individual (Sennett, 2009: 69)."

We know for sure the Renaissance artist was the person with authority in the atelier, he had power and distinctive talents but it was the apprentice painting or sculpting. The artist did overall design and maybe painted the "most expressive parts" but the apprentices produced his pictures. Or created "pictures in his manner (Sennett, 2009:69)."

In his book Travels in Hyperreality, Umberto Eco goes further and deals with the issue of originality in imaginary worlds and copied landscapes in America. First he investigates the copied sculptures at Ringling Museum of Art in Florida. Although some of the artifacts the museum houses are genuine, some are not. More importantly those fake items have a bronze plaque stating that they are copies. "But what is the meaning of 'fake' when applied to a platers cast or a bronze recasting?" Eco asks, he also poses more intriguing questions:

"We read one of the plaques at random: 'Dancer.
Modern cast in bronze from a Greek original of the fifth century B.C. The original [or rather the Roman copy] is in the Museo Nazionale in Napels.' So? The European museum has a Roman copy. But those are copies of a sculpture, where if you observe certain technical criteria nothing is lost (Eco, 2002: 36)."

Here, Eco poses an interesting question: "But what would happen to the visitor who, a thousand years hence, visited these mementoes, ignorant of a Europe long since vanished? (Eco, 2002: 36)." Apart from the definition and the value it conveys, the idea of originality can be taken to another dimension in the case of Disneyland and how we perceive the place. Here, Eco compares Disneyland to a place of ultimate fakes: "the Wax Museum and suggests that Disneyland is more hyperrealistic, because within its magic world it is absolute fantasy whereas the Wax Museum is merely reproducing the reality (Eco, 2002: 43)." Implying that the area between genuine and fake is totally grey and blurred, there are no set instructions to follow when it comes to defining authenticity. "Originality is hard to write down in a rulebook you might pack in your luggage (Sennett, 2009: 70)."

\section{CONCLUSION}

This paper began with a discussion on a few ordinary copies of a well known artist's work. The work of the artist is so immersed in the culture of Sweden, it is a known fact that his work has a lot of copies too. Given the examples of Walter Benjamin, Hito Steyerl and Umberto Eco it is obvious that the discussion on authenticity and reproduction is not new, different times brought new debates on the issue of reproduction and the distribution of images as well as shedding a different light on issues of authenticity. How do people judge originality themselves? What are the values they attribute to authentic objects? According to Sennett the idea of what is authentic is quite an obscure one. Because the judgement 
can be given by the consumer as well as the maker.

What the Carlsson brothers created was almost like citing an artist's work, the work belonged to John Bauer and they were well aware of the significance of the artist in popular Swedish culture. They were not questioning his works conceptually as employed by artists instead they created a variation of his work with the help of craft making methods, methods they were used to and methods they perfected through time with repetition. It helped them blur the area between arts and crafts and create a bridge between Sennett's view of Craftsman, Umberto Eco's idea of the vagueness of fakes and forgeries as well as a whole history of conceptual art. Carlsson brothers did not belong to any field specifically and their works were neither artworks nor were they just merely crafts, they were in between. They belong to a grey area, they unconsciously created an adaptation, and referenced an artists work. Contrary to the tradition of the conventional craft making atelier, their additions, interpretations, perspective and signatures (inscription) mattered. By moving beyond the limits of their own practice they stumbled upon a new way of operating.

With free interpretations of John Bauer's works the Carlsson brothers unintentionally addressed the issue of authorship. They were aware it was John Bauer's work, yet the public was very keen on acquiring the works, as gifts to their children or employees. They were masterfully carved attractive objects in themselves. The workshop was close to their homes, people knew the craftsmen and the "originals" who liked hanging out at the workshop. Some of the added value of the Bauer carvings came from being part of a local history and local culture and these valued carvings have in time come to remind people of a time in the past which they like to reflect on, revisit and ponder. In this case the consumer made a judgement about the originality and the value of the work. 


\section{REFERENCES}

- $\quad$ Ades, D., Cox, N., Hopkins, D. (1999). Marcel Duchamp. London: Thames and Hudson.

- Arvidsson, H. (2009). Swedish Crafts and Craft Education. Studies In Design Education Craft \& Technology, 21(3). https://ojs. lboro.ac.uk/SDEC/article/view/923 (Accessed 10. December. 2020)

- $\quad$ Benjamin, W. (1988). Illuminations, New York: Random House.

- $\quad$ Boym, S. (2009). Nostaljinin Geleceği, (Çev. F. Aydar) Istanbul: Iletişim Yayınları.

- $\quad$ Eco U. (1992). The Original and the Copy. In: Varela F.J., Dupuy JP. (eds) Understanding Origins. Boston Studies in the Philosophy and History of Science, vol 130. Springer, Dordrecht. https://doi.org/10.1007/978-94-015-8054-0_15 (Accessed 10. December. 2020).

- Eco, U. (2002). Travels in Hyperreality, New York: Harcourt Books.

- Salomon, O. (2013). Teacher's Hand-book of Slojd, North Carolina: Toolemara Press

- Skobe, T. (2008). Inte Bara En Verkstad, Floby: Co-print.

- $\quad$ Sennett, R. (2009). The Craftsman, London: Penguin Books.

- (2017). Swedish Folk Stories, Edinburgh: Floris Books.

- $\quad$ Steyerl, H. (2012). The Wretched of the Screen, Berlin: Sternbeg Press.

- Şahiner, R. (2008). Sanatta Postmodern Kirilmalar, Istanbul: Yeni İnsan.

- $\quad$ http-1: http://www.bildhuggarverkstad.com (Accessed 21. May. 2020).

- $\quad$ http-2: http://www.bildhuggarverkstad.com/chapterthree/ (Accessed 22.May.2020).

- $\quad$ http-3:http://www.ibe.unesco.org/sites/default/files/salomone.PDF (Accessed 5.December. 2020).

- $\quad$ http-4: https://www.e-flux.com/journal/10/61362/in-defense-of-the-poor-image/ (Accessed 02.December. 2020).

\section{Image References}

- Image 1: PJ Carlsson's workshop in 2020, Film Still, Personal Archive.

- Image 2: Tor Carlsson, the Troll Ride, Motala, Catherine Bolehed Collection.

- Image 3: (2017). Swedish Folk Stories, Edinburgh: Floris Books.

- Image 4: Tor Carlsson, "Leap the Elk", Istanbul, Private Collection.

- Image 5: Tor Carlsson, "Leap the Elk", Istanbul, Private Collection.

- Image 6: Gösta Nyberg "Princess Cottongrass", Jönköping, Peter Nyberg Collection. 